\title{
Research Article \\ Antidiabetic Activity of Extract Combination of Orthosiphon aristatus and Oryza sativa L. var glutinosa
}

Eris Septiana ${ }^{*}$
Nurul Maulida Rizka ${ }^{2}$
Yadi ${ }^{*}$
Partomuan Simanjuntak 2,3
1Research Center for Biotechnology,
Indonesian Institute of Sciences, Bogor,
West Java, Indonesia
2Department of Pharmacy, Universitas
Pancasila, South Jakarta, Jakarta Capital
Special Region, Indonesia
3Research Center for Chemistry,
Indonesian Institute of Sciences, South
Tangerang, Banten, Indonesia
*email: septiana.eris@gmail.com
Keywords:
a-glucosidase
Antidiabetic
Extract combination
Orthosiphon aristatus
Oryza sativa L. var. glutinosa

\begin{abstract}
Traditionally and scientifically, research has shown that Orthosiphon aristatus and Oryza sativa L. var. glutinosa have antidiabetic activity. The combination of two medicinal plants can increase their biological activity. This study aimed to determine the antidiabetic activity of $O$. aristatus and $O$. sativa L. var. glutinosa on single and combined extracts. Phytochemical screening of the single extract was done qualitatively. The a-glucosidase inhibitory method was used as an antidiabetic activity. The results showed that every extract contained alkaloids, steroids/triterpenoids, flavonoids, tannins, quinones, and coumarins. A single extract of $O$. sativa $\mathrm{L}$. var glutinosa, $O$. aristatus, and their combinations (1:1, 1:2, and 2:1) had an a-glucosidase enzyme inhibitory activity with an $\mathrm{IC}_{50}$ value of $67.82,80.93,73.81,88.72$, and $61.51 \mu \mathrm{g} / \mathrm{ml}$, respectively. The combination shows that the ratio of 1:1 was nearly additive, 1:2 was slight to moderate antagonism, and 2:1 was moderate to slight synergism. The combination of $96 \%$ ethanol extract of $O$. sativa L. var. glutinosa and O. aristatus in a ratio of 2:1 was the most effective in increasing its inhibitory activity.
\end{abstract}

Received: February 22th, 2021

Accepted: August 5th, 2021

Published: August 30th, 2021

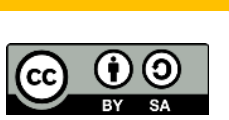

(c) 2021 Eris Septiana, Nurul Maulida Rizka, Yadi, Partomuan Simanjuntak. Published by Institute for Research and Community Services Universitas Muhammadiyah Palangkaraya. This is an Open Access article under the CC-BY-SA License https:// doi.org/10.33084/bjop.v4i3.2154

\section{INTRODUCTION}

Diabetes mellitus (DM) is a condition in which an increase in blood sugar levels (hyperglycemia) that caused by a decrease in insulin secretion and activity ${ }^{1}$. It is because of the damage in the metabolic system, especially carbohydrates, fats, and proteins. Diabetes mellitus is one of five diseases with a high number of cases and death rates worldwide. The recent report estimates that diabetes mellitus attacked more than 463 million people worldwide and around 4.2 million of them died in $2019^{2}$. According to the Indonesian Health Ministry report, about 16.5 million Indonesians aged over
15 years were diagnosed with diabetes in 2018. In diabetic patients, the production of free radicals will be higher due to the auto-oxidation process of glucose ${ }^{3}$.

Although diabetes mellitus is a chronic disease that does not cause immediate death, it can be fatal if the curing management is not proper. Management of diabetes mellitus requires drug therapy and non-drug therapy. Acarbose, a class of a-glucosidase enzyme inhibitors, is one of the drug therapies used in diabetic patients ${ }^{4}$. The a-glucosidase enzyme is an enzyme that plays a role in the breakdown of carbohydrates into glucose in the digestive tract to control glucose absorption ${ }^{5}$. Treatment of diabetes takes a lifetime at a relatively high cost. In 
addition to treatment with synthetic drugs, natural drugs as antidiabetics are increasingly in demand. Although the effects of plant-derived compounds are not as effective as synthetic drugs, the risk of the side effects seems to be very rare ${ }^{6}$. Some natural medicines have been used for generations, but research ensures their efficacy and safety ${ }^{7}$.

Research on black glutinous rice (Oryza sativa L. var. glutinosa) has been carried out previously in the in vivo study. The water extract of O. sativa L. var. glutinosa can reduce blood glucose levels, with the highest dose at 500 $\mathrm{mg} / \mathrm{kg} \mathrm{BW}$. In addition to O. sativa L. var. glutinosa, the Cat's whiskers tea or Java tea (Orthosiphon aristatus) is also used as traditional antidiabetic medicine. The 50\% ethanol extract of $O$. aristatus can inhibit the a-glucosidase enzyme with an $\mathrm{IC}_{50}$ value of $4.63 \mathrm{mg} / \mathrm{mL}^{8}$. Meanwhile, Juliani et al. ${ }^{9}$ reported that methanol extract of $O$. aristatus inhibited the a-glucosidase enzyme with an $\mathrm{IC}_{50}$ value of $465.83 \mu \mathrm{g} / \mathrm{mL}$.

In addition to a single extract, several studies have also used a combination of two different types of plants for aglucosidase enzyme inhibitory activity. To optimize the utilization of medicinal plant extracts as antidiabetic, combining them could be the best alternative for diabetic treatment. A previous study showed that the combination of Eurycoma longifolia and Punica granatum extracts could increase the inhibitory activity of the aglucosidase enzyme compared to their respective single form $^{10}$. Every extract of $O$. sativa L. var. glutinosa and $O$. aristatus has antidiabetic activity by inhibiting the aglucosidase enzyme. Moreover, the combination of extracts can increase the inhibitory activity of the aglucosidase enzyme. Therefore, this study aimed to determine the antidiabetic activity of $O$. sativa L. var. glutinosa and $O$. aristatus on single and combined extracts by inhibiting the a-glucosidase enzyme.

\section{MATERIALS AND METHODS}

\section{Materials}

-nitrophenyl-a-D-glucopyranose (PNPG) (Sigma), aglucosidase enzyme from Sacharomyces cerevisiae (Sigma), acarbose (Sigma), 96\% ethanol (Brataco), nhexane (Brataco), ethyl acetate (Brataco), methanol (Brataco), distilled water (Brataco), hydrochloric acid (Merck), ammonia (Merck), chloroform (Merck), potassium iodide (Merck), ether (Merck), anhydrous acetic acid (Merck), sulfuric acid (Merck), magnesium powder (Merck), amyl alcohol (Merck), sodium hydroxide (Merck), iron (III) chloride (Merck), dimethyl sulfoxide (DMSO) (Merck), potassium dihydrogen phosphate (Merck), dipotassium phosphate (Merck), sodium carbonate (Merck). The main instruments used in this study were analytical balance (Precisa 340A), incubator (Memmert), rotary vacuum evaporator (Janke \& Kunkel RV 05-ST), UV-Vis Spectrophotometer (Hitachi U-3900H).

\section{Methods}

Plant extraction

Oryza sativa L. var. glutinosa (BKH) and O. aristatus (KK) were obtained from Sri Rahayu Grocery Store and Indonesian Spice and Medicinal Crops Research Institute (Balittro), Bogor, West Java, respectively. The samples were identified in the Herbarium Bogoriense, Research Center for Biology, Indonesian Institute of Sciences, Bogor, with report number 2339/IPH.1.01/If.07/X/2018. All samples were washed with tap water and then cut into small pieces, specifically for KK. The samples were dried under the sunlight. One hundred grams of BKH and KK were put into separate glass jars. They were extracted six times with $96 \%$ ethanol for 24 hours, filtered, and stored. All the filtrates obtained were collected and evaporated on a rotary evaporator. The combination of extracts used in this research were 
1:1, 1:2, and 2:1 $(\mathrm{w} / \mathrm{w})^{11}$. All the extracts were weighed using analytical balance to determine the yield.

\section{Phytochemical screening}

Qualitative phytochemical screening was performed based on the standard procedures ${ }^{12}$.

\section{Antidiabetic activity assay}

A total of $1 \mathrm{mg}$ of an a-glucosidase enzyme from $S$. cerevisiae (9.8 units/mg) was dissolved in $1 \mathrm{~mL}$ of $0.01 \mathrm{M}$ phosphate buffer (pH7) as an enzyme stock solution (9.8 units $/ \mathrm{mL}$ ). Approximately $0.02 \mathrm{~mL}$ of the enzyme stock solution was dissolved to $5 \mathrm{~mL}$ in $0.01 \mathrm{M}$ phosphate buffer $(\mathrm{pH} 7)$ to obtain a working solution (0.04 units $/ \mathrm{mL}$ ). The single and combined extract solutions in DMSO concentrations were 6.25, 12.5, 25, 50, and 100 $\mu \mathrm{g} / \mathrm{mL}$. Acarbose (in water) at the concentration series of $3,6,9,12$, and $15 \mu \mathrm{g} / \mathrm{mL}$ were made as a positive control. A total of $475 \mu \mathrm{L}$ of $0.1 \mathrm{M}$ phosphate buffer (pH7), $250 \mu \mathrm{L}$ of $0.2 \mathrm{M}$ $\rho$-nitrophenyl-a-D-glucopyranoside ( $\mathrm{NPG}$ ), and $25 \mu \mathrm{L}$ of each extract were put into a test tube. Then, they were incubated at $37^{\circ} \mathrm{C}$ for 5 minutes, followed by adding $250 \mu \mathrm{L}$ of the enzyme solution and re-incubated at $37^{\circ} \mathrm{C}$ for 30 minutes. The enzyme reaction was stopped by added $1000 \mu \mathrm{L}$ of $0.2 \mathrm{M}$ sodium carbonate solution.

The inhibitory activity of a-glucosidase was calculated based on the absorption values at the wavelength of 400 nm using a UV-Vis spectrophotometer ${ }^{13}$. The $\mathrm{IC}_{50}$ value, whereas the extract concentration can inhibit $50 \%$ of the a-glucosidase enzyme activity, was calculated based on the linear regression equation ${ }^{14}$.

\section{Extract combination analysis}

The inhibitory activity of the a-glucosidase enzyme from the combined extract was calculated using the combination index ${ }^{15}$ between BKH and KK through the following Formula 1.

$$
\text { Combination index }=\frac{D 1}{(D x) 1}+\frac{D 2}{(D x) 2} \ldots[1]
$$

Dx1 and Dx2 were the concentrations of one single extract needed to give effect $\left(\mathrm{IC}_{50}\right.$ on the a-glucosidase enzyme activity), while D1 and D2 were the concentration of the two extracts (combination) to give the same effect. The results of Combination Index $(\mathrm{CI})$ were interpreted as follows: <0.1: very strong synergism; 0.1-0.3: strong synergism; 0.3-0.7: synergism; 0.7-0.9: moderate to slight synergism; 0.9-1.1: nearly additive;1,11.45: slight to moderate antagonism; 1.45-3.3: antagonism; and >3.3: strong to very strong antagonism $^{16}$.

\section{RESULTS AND DISCUSSION}

Plant extraction

The percentage of yields was obtained from the ratio of the extract and the number of herbal substances. In this study, the yield of KK extract was higher than BKH extract. The solvent used for extraction is more efficient in attracting the compound in the KK than BKH extract. A high yield value can indicate the number of bioactive compounds contained. Likewise, the higher the yield percentage, the more bioactive compounds contained $\operatorname{in}^{17}$. Therefore, we can assume that more bioactive components in KK compare to BKH extract. Table I showed that the $96 \%$ ethanol extract weight of $\mathrm{BKH}$ and KK were 7.29 and $21.56 \mathrm{~g}$, and the yields were $7.27 \%$ and $21.52 \%$, respectively.

Table I. Yield of $96 \%$ ethanol extract

\begin{tabular}{lccc}
\hline Extracts & $\begin{array}{c}\text { Weight of } \\
\text { simplicia } \mathbf{( g )}\end{array}$ & $\begin{array}{c}\text { Weight of } \\
\text { extracts } \mathbf{( g )}\end{array}$ & $\begin{array}{c}\text { Yields } \\
\mathbf{( \% )}\end{array}$ \\
\hline BKH & 100.3 & 7.29 & 7.27 \\
KK & 100.2 & 21.56 & 21.52 \\
\hline
\end{tabular}

\section{Phytochemical screening}

The phytochemical screening results of BKH and KK extracts were presented in Table II. It shows that the 96\% ethanol extract of the KK did not contain triterpenoids and saponins. In contrast, the $96 \%$ ethanol extract of BKH did not contain steroid and saponin compounds. 
The bioactive components in a medicinal plant extract are related to their biological activity. The $96 \%$ ethanol extract of KK and BKH contains various chemical compounds, roleplaying a vital role in inhibiting the activity of the aglucosidase enzyme. Several studies reported that all compounds detected in these phytochemical screening tests have antidiabetic activity. The flavonoids were reported to have several types of inhibitory activity for the a-glucosidase enzyme, including in competitive, noncompetitive, and mixed manner by receiving or donating protons to form hydrogen bonds with the active site the enzyme $^{18}$. The presence of hydrogen bonds between flavonoids and enzymes will allow flavonoids to regulate glucose absorption to achieve stability of glucose levels through the disaccharide pathway, inhibitory effect on maltase enzyme activity, and decreases glycemia before glucose abundance ${ }^{19}$.

Table II. Phytochemical screening of $96 \%$ ethanol extract of $\mathrm{BKH}$ and $\mathrm{KK}$

\begin{tabular}{|c|c|c|}
\hline \multirow{2}{*}{ Compounds } & \multicolumn{2}{|c|}{ Results } \\
\hline & BKH & KK \\
\hline \multirow[t]{4}{*}{ Alkaloids } & A thick red & A thick red \\
\hline & precipitate & precipitate \\
\hline & formed with & formed with \\
\hline & Dragendorff's* & Dragendorff's* \\
\hline Steroids & $\begin{array}{l}\text { No blue or green } \\
\text { color formed }\end{array}$ & $\begin{array}{l}\text { A green color was } \\
\text { formed* }\end{array}$ \\
\hline Triterpenoids & $\begin{array}{l}\text { A red color was } \\
\text { formed* }\end{array}$ & $\begin{array}{l}\text { No red color } \\
\text { formed }^{* *}\end{array}$ \\
\hline Flavonoids & $\begin{array}{l}\text { A red solution was } \\
\text { formed in organic } \\
\text { layer* }\end{array}$ & $\begin{array}{l}\text { A red solution was } \\
\text { formed in organic } \\
\text { layer* }\end{array}$ \\
\hline Saponins & $\begin{array}{l}\text { A stable foam not } \\
\text { formed after } \\
\text { shaking** }\end{array}$ & $\begin{array}{l}\text { A stable foam not } \\
\text { formed after } \\
\text { shaking** }\end{array}$ \\
\hline Tannins & $\begin{array}{l}\text { A greenish black } \\
\text { solution } \\
\text { formed* }^{*}\end{array}$ & $\begin{array}{l}\text { A greenish black } \\
\text { solution } \\
\text { formed* }^{*}\end{array}$ \\
\hline Quinons & $\begin{array}{l}\text { A red solution was } \\
\text { formed* }\end{array}$ & $\begin{array}{l}\text { A red solution was } \\
\text { formed* }\end{array}$ \\
\hline \multirow[t]{2}{*}{ Qoumarins } & A fluorescence & A fluorescence \\
\hline & $\begin{array}{l}\text { solution was formed } \\
\text { under UV light* }\end{array}$ & $\begin{array}{l}\text { solution was } \\
\text { formed under UV } \\
\text { light* }\end{array}$ \\
\hline
\end{tabular}

Alkaloids have been reported can inhibit the aglucosidase enzyme competitively ${ }^{20}$ or noncompetitively ${ }^{21}$. Inhibition of alkaloids against the aglucosidase enzyme has several mechanisms, including the formation of hydrogen bonds, hydrophobic interactions, and cations ${ }^{22}$. Steroids also have the activity of inhibiting the activity of the a-glucosidase enzyme through the hydrophobic interaction pathway with enzyme attachment site as a target ${ }^{23}$. These compounds configure the hydrogen bonds with the enzyme's active site $^{24}$. The terpenoid compounds were reported to have non-competitive a-glucosidase enzyme inhibitory activity via the formation of hydrogen and hydrophobic bonds with the enzyme's active site ${ }^{25}$.

Tannin groups were reported as antidiabetic by noncompetitive inhibition of the a-glucosidase enzyme ${ }^{26}$. Furthermore, tannin configures the hydrogen bonds with the enzyme's active site ${ }^{27}$. Coumarin has been reported as antidiabetic by inhibiting the a-glucosidase enzyme. This compound has non-competitive inhibition via hydrogen bonds with the enzyme's active site ${ }^{28}$. Emodin, one of the compounds in the quinone groups, was reported to have an inhibitory activity to the aglucosidase enzyme through increasing glucose absorption $^{29}$.

\section{Antidiabetic activity assay}

The a-glucosidase enzyme inhibitory activity from the single extract of BKH and KK and their combination (1:1, 1:2, and 2:1) were presented in Tables III to V. In this study, KK's 96\% ethanol extract had an inhibitory activity of the a-glucosidase enzyme with an $\mathrm{IC}_{50}$ value of 80.93 $\mu \mathrm{g} / \mathrm{mL}$. This value was better than in the research conducted by Juliani et al. ${ }^{9}$, which reported that the $\mathrm{IC}_{50}$ value of $O$. aristatus butanol extract was $154.07 \mu \mathrm{g} / \mathrm{mL}$. In 96\% ethanol extract, BKH had a-glucosidase enzyme inhibitory activity with $\mathrm{IC}_{50}$ of $67.82 \mu \mathrm{g} / \mathrm{mL}$. The activity in this study was slightly lower than the inhibitory activity of the a-glucosidase enzyme from methanol extract of O. sativa L. var. glutinosa RF6 that had an $\mathrm{IC}_{50}$ value of $54.93 \mu \mathrm{g} / \mathrm{mL}^{30}$. These gaps occur due to different places where they grow and the type of solvent that 
affects the content of bioactive compounds in extracts of medicinal plants 31,32 .

Table III. Analysis of the inhibitory activity of the aglucosidase enzyme from the $96 \%$ ethanol extract of KK and BKH

\begin{tabular}{ccc}
\hline $\begin{array}{c}\text { Concentration } \\
(\mu \mathrm{g} / \mathrm{mL})\end{array}$ & \multicolumn{2}{c}{ Enzyme inhibition activity $(\%)$} \\
\cline { 2 - 3 } & $\mathbf{K K}$ & $\mathbf{B K H}$ \\
\hline 6.25 & $14.84 \pm 1.12$ & $12.00 \pm 1.00$ \\
12.5 & $25.59 \pm 0.99$ & $26.33 \pm 1.15$ \\
25 & $32.69 \pm 0.99$ & $27.67 \pm 1.53$ \\
50 & $44.30 \pm 0.37$ & $38.00 \pm 1.73$ \\
100 & $53.98 \pm 4.30$ & $68.00 \pm 2.65$ \\
\hline
\end{tabular}

Table IV. Analysis of the inhibitory activity of the aglucosidase enzyme combination from the $96 \%$ ethanol extract of KK and BKH

\begin{tabular}{cccc}
\hline \multirow{2}{*}{$\begin{array}{c}\text { Concentration } \\
(\boldsymbol{\mu g} / \mathbf{m L})\end{array}$} & \multicolumn{3}{c}{ Enzyme inhibition activity (\%) } \\
\cline { 2 - 4 } & $\begin{array}{c}\text { BKH-KK } \\
\mathbf{( 1 : 1 )}\end{array}$ & $\begin{array}{c}\text { BKH-KK } \\
\mathbf{( 1 : 2 )}\end{array}$ & $\begin{array}{c}\text { BKH-KK } \\
(\mathbf{2 : 1 )}\end{array}$ \\
\hline 6.25 & $5.52 \pm 0.38$ & $8.33 \pm 0.58$ & $11.26 \pm 0.66$ \\
12.5 & $21.63 \pm 0.38$ & $13.00 \pm 1.00$ & $23.40 \pm 0.76$ \\
25 & $33.33 \pm 0.38$ & $26.67 \pm 0.58$ & $42.16 \pm 1.38$ \\
50 & $45.25 \pm 1.53$ & $34.00 \pm 1.00$ & $48.79 \pm 0.38$ \\
100 & $58.06 \pm 0.38$ & $53.33 \pm 1.53$ & $65.56 \pm 0.66$ \\
\hline
\end{tabular}

Table V. The $\mathrm{IC}_{50}$ value of the a-glucosidase enzyme inhibition extract of KK and BKH

\begin{tabular}{lc}
\hline \multicolumn{1}{c}{ Materials test } & IC $_{50}(\mu \mathrm{g} / \mathrm{mL})$ \\
\hline KK & $80.93 \pm 7.58$ \\
BKH & $67.82 \pm 3.06$ \\
BKH-KK (1:1) & $73.81 \pm 1.02$ \\
BKH-KK $(1: 2)$ & $88.72 \pm 2.63$ \\
BKH-KK (2:1) & $61.51 \pm 1.15$ \\
Acarbose (positive control) & $14.68 \pm 0.03$ \\
\hline
\end{tabular}

In carbohydrate metabolism, carbohydrates entering the digestive tract would be digested into simpler sugars and then absorbed by the small intestine. The a-glucosidase is an enzyme commonly used for in vitro antidiabetic activity assay. It is commonly found in the small intestine and converts disaccharides into monosaccharide carbohydrates $^{33}$. Therefore, inhibition of the aglucosidase enzyme activity will reduce the breakdown of disaccharides into glucose which eventually reduces the blood glucose levels ${ }^{34}$. In the in vitro study, the aglucosidase enzyme hydrolyzes the substrate $\rho$ nitrophenyl-a-D-glucopyranoside to become yellow $\rho$ nitrophenyl and glucose ${ }^{35}$.

\section{Extract combination analysis}

The effectiveness of the combination $96 \%$ ethanol extract

$\mathrm{BKH}$ and KK on a-glucosidase enzyme inhibition, with the Combination Index $(\mathrm{CI})$ value as the analysis parameter, were presented in Table VI. The use of a combination of extracts with a low ratio is a simple initial step to determine the effect of each extract on efficacy and toxicity. This is essential as initial data to determine which extract influences the efficacy and toxicity when the extract is combined so that the ratio of the combination of extracts to be used can be estimated ${ }^{36,37}$.

A single extract of $\mathrm{KK}$ and $\mathrm{BKH}$ has a good antidiabetic activity via inhibition of the a-glucosidase enzyme. The antidiabetic activity of the plant extracts can be improved by combining them. The combination of E. longifolia and $P$. granatum extracts can increase the inhibitory activity of the a-glucosidase enzyme compared to their respective single extract ${ }^{10}$. In this study, the combination of the $96 \%$ ethanol extract of $\mathrm{BKH}$ and $\mathrm{KK}(2: 1)$ had a lower $\mathrm{IC}_{50}$ value than the single one. This result indicated that the combination shows a synergism effect. It is in line with previous studies which reported that the plant extracts combination can increase the inhibition activity of the aglucosidase enzyme ${ }^{38}$. The synergism effect is a positive interaction of two or more substances that show a higher mechanism than the sum of the single substance ${ }^{39}$.

Table VI. The index value of the combination of $96 \%$ ethanol extract of KK and $\mathrm{BKH}$ on inhibition of the aglucosidase enzyme

\begin{tabular}{ccl}
\hline Ratio of BKH-KK & CI values & \multicolumn{1}{c}{ Categories } \\
\hline $1: 1$ & 1.0003 & $\begin{array}{l}\text { nearly additives } \\
\text { slight to moderate } \\
\text { antagonism } \\
\text { moderate to slight } \\
\text { synergism }\end{array}$ \\
$2: 1$ & 0.1669 & \\
\hline
\end{tabular}

In addition to the synergism effect, the combination of extracts can also have additive and antagonism effects. In this study, the combination of $96 \%$ ethanol extract with a ratio of 1:1 produced a nearly additive effect. The combination of $96 \%$ ethanol extract of BKH and KK with 
a combination of 1:2 has a slight to moderate antagonism effect. An additive effect occurs when the combination only has a biological enhancement effect from its single extracts. An antagonist effect occurs when the combination shows lower activity than every extract ${ }^{38}$. The additive and antagonism effects also occur in previous studies. Marianne et al. ${ }^{11}$ reported that the combination of the ethanol extract of Curcuma heyneana rhizome and Curanga fel-terrae leaf with a 1:1 and 2:1 ratio had CI values at 1.09 and 1.21, respectively.

\section{CONCLUSION}

Both single and the combination of the $96 \%$ ethanol extract of $O$. aristatus and $O$. sativa L. var. glutinosa have an inhibitory activity of the a-glucosidase enzyme. The $96 \%$ ethanol extract of O. sativa L. var. glutinosa has better inhibitory activity than $O$. aristatus. The combination of $96 \%$ ethanol extract of $O$. sativa L. var. glutinosa and $O$. aristatus in a ratio of 2:1 is the most effective to increase the inhibitory activity.

\section{ACKNOWLEDGMENT}

We acknowledge support from the Natural Product Chemistry Laboratory, Research Center for Biotechnology, Indonesian Institute of Sciences for the laboratory facilities.

\section{AUTHORS' CONTRIBUTION}

Eris Septiana: supervision, conceptualization, antidiabetic activity, extract combination analysis, data entry and analysis. Nurul Maulida Rizka: antidiabetic activity, phytochemical screening, data analysis. Yadi: extraction. Partomuan Simanjuntak: supervision, conceptualization, phytochemical screening.

\section{DATA AVAILABILITY}

None.

\section{CONFLICT OF INTEREST}

The authors declare no conflict of interest.

\section{REFERENCES}

1. Cantley J, Ashcroft FM. Q\&A: insulin secretion and type 2 diabetes: why do $\beta$-cells fail? BMC Biol. 2015;13:33. doi:10.1186/s12915-015-0140-6

2. Saeedi P, Petersohn I, Salpea P, Malanda B, Karuranga S, Unwin N, et al. Global and regional diabetes prevalence estimates for 2019 and projections for 2030 and 2045: Results from the International Diabetes Federation Diabetes Atlas, 9th edition. Diabetes Res Clin Pract. 2019;157:107843. doi:10.1016/j.diabres.2019.107843

3. Mahmoodnia L, Aghadavod E, Beigrezaei S, Rafieian-Kopaei M. An update on diabetic kidney disease, oxidative stress and antioxidant agents. J Renal Inj Prev. 2017;6(2):153-7. doi:10.15171/jrip.2017.30

4. Marín-Peñalver JJ, Martín-Timón I, SevillanoCollantes C, del Cañizo-Gómez FJ. Update on the treatment of type 2 diabetes mellitus. World J Diabetes. 2016;7(17):354-95. doi:10.4239/wjd.v7.i17.354

5. Alqahtani AS, HidayathullaS, Rehman MT, ElGamal AA, Al-Massarani S, Razmovski-Naumovski V, et al. Alpha-Amylase and Alpha-Glucosidase Enzyme Inhibition and Antioxidant Potential of 3-Oxolupenal and Katononic Acid Isolated from Nuxia oppositifolia. Biomolecules. 2020;10(1):61. doi:10.3390/biom10010061

6. Tabatabaei-Malazy O, Larijani B, Abdollahi M. Targeting metabolic disorders by natural products. J Diabetes Metab Disord. 2015,14:57. doi:10.1186/s40200-015-0184-8

7. Iryani I, Iswendi I, Katrina IT. Uji Aktivitas Anti Diabetes Mellitus Senyawa Metabolit Sekunder Fraksi Air Dari Beras Ketan Hitam (Oryza satival. Var glutinosa) Pada Mencit Putih. Eksakta Berkala Ilmiah Bidang MIPA. 2017;18(1):54-60. doi:10.24036/eksakta/vol18-iss01/17 
8. Mohamed EAH, Siddiqui MJA, Ang LF, Sadikun A, Chan SH, Tan SC, et al. Potent a-glucosidase and aamylase inhibitory activities of standardized 50\% ethanolic extracts and sinensetin from Orthosiphon stamineus Benth as anti-diabetic mechanism. BMC Complement Altern Med. 2012;12:176. doi:10.1186/1472-6882-12-176

9. Juliani, Yuliana ND, Budijanto S, Wijaya CH, Khatib A. Senyawa Inhibitor a-Glukosidase Dan Antioksidan Dari Kumis Kucing Dengan Pendekatan Metabolomik Berbasis FTIR. Jurnal Teknologi dan Industri Pangan. 2016;27(1):17-20. doi:10.6066/jtip.2016.27.1.17

10. Abdulmunem OK, Makky EA, Tawfiq AA, Mahendran K, Zamri N. Evaluating the Effect of Combined Plant Extracts on a-amylase and aglucosidase Inhibition Activity as Antidiabetic Agents. Pak J Biol Sci. 2020;23(3):287-94. doi:10.3923/pjbs.2020.287.294

11. Marianne M, Patilaya P, Barus BT. Uji Aktivitas Antioksidan Kombinasi Ekstrak Etanol Rimpang Temu Giring (Curcuma Heyneana) dan Daun Pugun Tanoh (Curanga Fel-Terrae) Menggunakan Metode Diphenyl Picrylhydrazil(DPPH). Talenta Conf Ser Trop Med (TM). 2018;1(2):398-404.

12. Harborne JB, Niksoliin S, Padmawinata K, Sudiro I. Metode Fitokimia: Penuntun Cara Modern Menganalisis Tumbuhan. Bandung: ITB Press; 1996.

13. Saijyo J, Suzuki Y, Okuno Y, Yamaki H, Suzuki T, Miyazawa M. Alpha-glucosidase inhibitor from Bergenia ligulate. J Oleo Sci. 2008;57(8):431-5. doi:10.5650/jos.57.431

14. Mugaranja KP, Kulai A. Alpha glucosidase inhibition activity of phenolic fraction from Simarouba glauca: An in-vitro, in-silico and kinetic study. Heliyon. 2020;6(7):e04392. doi:10.1016/j.heliyon.2020.e04392

15. Chou TC. Theoretical basis, experimental design, and computerized simulation of synergism and antagonism in drug combination studies. Pharmacol Rev. 2006;58(3):621-81. doi:10.1124/pr.58.3.10

16. Reynolds $\mathrm{CP}$, Maurer BJ. Evaluating response to antineoplastic drug combinations in tissue culture models. Methods Mol Med. 2005;110:173-83. doi:10.1385/1-59259-869-2:173

17. Zhang QW, Lin LG, Ye WC. Techniques for extraction and isolation of natural products: a comprehensive review. Chin Med. 2018113:20. doi:10.1186/s13020-018-0177-x

18. Proença C, Freitas M, Ribeiro D, Oliveira EFT, Sousa JLC, Tomé SM, et al. a-Glucosidase inhibition by flavonoids: an in vitro and in silico structure-activity relationship study. J Enzyme Inhib Med Chem. 2017;32(1):1216-28.

doi:10.1080/14756366.2017.1368503

19. Pereira DF, Cazarolli LH, Lavado C, Mengatto V, Figueiredo MSRB, Guedes A, et al. Effects of flavonoids on a-glucosidase activity: potential targets for glucose homeostasis. Nutrition. 2011;27(1112):1161-7. doi:10.1016/j.nut.2011.01.008

20. Gao H, Huang YN, Li P, Inagaki C, Kawabata J. Inhibitory effect on a-glucosidase by Adhatoda vasica Nees. Food Chem. 2008;108(3):965-72. doi:10.1016/j.foodchem.2007.12.002

21. Kim SD. a-Glucosidase inhibitor from Buthus martensi Karsch. Food Chem. 2013;136(2):297-300. doi:10.1016/j.foodchem.2012.08.063

22. Zafar M, Khan H, Rauf A, Khan A, Lodhi MA. In Silico Study of Alkaloids as a-Glucosidase Inhibitors: Hope for the Discovery of Effective Lead Compounds. Front Endocrinol. 2016;7:153. doi:10.3389/fendo.2016.00153

23. Abuelizz HA, Anouar EH, Ahmad R, Azman NIIN, Marzouk M, Al-Salahi R. Triazoloquinazolines as a new class of potent a-glucosidase inhibitors: in vitro evaluation and docking study. PLoS One. 2019;14(8):e0220379. doi:10.1371/journal.pone.0220379

24. Ur Rehman N, Rafiq K, Khan A, Halim SA, Ali L, AlSaady $\mathrm{N}$, et al. a-Glucosidase Inhibition and Molecular Docking Studies of Natural Brominated Metabolites from Marine Macro Brown Alga Dictyopteris hoytii. Mar Drugs. 2019;17(12):666. doi:10.3390/md17120666

25. Elsbaey M, Mwakalukwa R, Shimizu K, Miyamoto T. Pentacylic triterpenes from Lavandula coronopifolia: structure related inhibitory activity on a-glucosidase. Nat Prod Res. 2021;35(9):1436-444. doi:10.1080/14786419.2019.1655017

26. Hossain U, Das AK, Ghosh S, Sil PC. An overview on the role of bioactive a-glucosidase inhibitors in ameliorating diabetic complications. Food Chem Toxicol. 2020;145:111738. doi:10.1016/j.fct.2020.111738 
27. Abdelli I, Benariba N, Adjdir S, Fekhiker Z, Daoud I, Terki $\mathrm{M}$, et al. In silico evaluation of phenolic compounds as inhibitors of A-amylase and Aglucosidase. J Biomol Struct Dyn. 2021;39(3):816-22. doi:10.1080/07391102.2020.1718553

28. Wang G, Wang J, He D, Li X, Li J, Peng Z. Synthesis, in vitro evaluation and molecular docking studies of novel coumarin-isatin derivatives as a-glucosidase inhibitors. Chem Biol Drug Des. 2017;89(3):456-63. doi:10.1111/cbdd.12867

29. Jung HA, Ali MY, Choi JS. Promising Inhibitory Effects of Anthraquinones, Naphthopyrone, and Naphthalene Glycosides, from Cassia obtusifolia on a-Glucosidase and Human Protein Tyrosine Phosphatases 1B. Molecules. 2016;22(1):28. doi:10.3390/molecules22010028

30. Sasenya S, Nanok K. a-glucosidase, a-amylase inhibitory potential and antioxidant activity of fragrant black rice (Thai coloured rice). Flavour Fragr J. 2020;35(4):376-86. doi:10.1002/ffj.3572

31. Rafi M, Purwakusumah ED, Ridwan T, Barus B, Sutandi A, Darusman, LK. Geographical classification of Java Tea (Orthosiphon stamineus) from Java Island by FTIR Spectroscopy Combined with Canonical Variate Analysis. MIPA. 2015;23(1):25-31.

32. Akowuah GA, Ismail Z, Norhayati I, Sadikun A. The effects of different extraction solvents of varying polarities on polyphenols of Orthosiphon stamineus and evaluation of the free radical-scavenging activity. Food Chem. 2005;93(2):311-7. doi:10.1016/j.foodchem.2004.09.028

33. Bhat M, Zinjarde SS, Bhargava SY, Kumar AR, Joshi BN. Antidiabetic Indian plants: a good source of potent amylase inhibitors. Evid Based Complement Alternat Med. 2011;2011:810207. doi:10.1093/ecam/nen040

34. Kwon YI, Apostolidis E, Shetty K. Evaluation of Pepper (Capsicum annuum) For Management of Diabetes and Hypertension. J Food Biochem. 2007;31(3):370-85. doi:10.1111/j.17454514.2007.00120.x

35. Djamil R, Winarti W, Simanjuntak P, Syamsudin. Standardization and a-glycosidase inhibition of extracts of Vatica pauciflora Blume stem barks and Smallanthus sonchifolius leaves. J Pharm Phytochem. 2014;3(4):42-6.
36. Argo BD, Wardani AK, Zubaidah E, Winarsih S. Endoglucanase, Exo-glucanase and Alphaglucosidase Activity the Combination of Crude Enzyme from Trichoderma reesei and Aspergillus niger at Different Temperatures and $\mathrm{pH}$. Res Rev Biosci. 2014;9(2):45-8.

37. Kesavanarayanan KS, Sathiya S, Ranju V, Sunil AG, llavarasan R, Babu CS, et al. In vitro cytotoxic, antioxidative and alpha-glucosidase inhibitory potential of a herbal mixture comprised of Allium sativum and Lagerstroemia speciose. Eur Rev Med Pharmacol Sci. 2012;16(Suppl 3):58-68.

38. Vinholes J, Vizzotto M. Synergisms in Alphaglucosidase Inhibition and Antioxidant Activity of Camellia sinensis L. Kuntze and Eugenia uniflora L. Ethanolic Extracts. Pharmacognosy Res. 2017;9(1):101-7. doi:10.4103/0974-8490.197797

39. Kuok CF, Hoi SO, Hoi CF, Chan CH, Fong IH, Ngok CK, et al. Synergistic antibacterial effects of herbal extracts and antibiotics on methicillin-resistant Staphylococcus aureus: A computational and experimental study. Exp Biol Med. 2017;242(7):73143. doi:10.1177/1535370216689828 